\title{
Setting landscape conservation targets and promoting them through compatible land use in the Philippines
}

Grace B. Villamor, Ruth Grace Ambal, Jean-Marc Boffa, Thomas Brookes, Angelito Cereno, Oliver Coroza, Rodel D. Lasco, Goetz Schroth and Merlijn van Weerd 


\section{Setting landscape conservation targets and promoting them through compatible land use in the Philippines}

Grace B. Villamor, Ruth Grace Ambal, Jean-Marc Boffa, Thomas Brookes, Angelito Cereno, Oliver Coroza, Rodel D. Lasco, Goetz Schroth and Merlijn van Weerd 


\section{(7) \\ World Agroforestry Centre \\ TRANSFORMING LIVES AND LANDSCAPES}

\section{Correct citation:}

GB Villamor, RG Ambal, JM Boffa, T Brookes, A Cereno, O Coroza, RD Lasco, G Schroth and M van Weerd. 2008. Setting landscape conservation targets and promoting them through compatible land use in the Philippines - a meeting-workshop of CI-ICRAF Collaborative Project. ICRAF Working Paper no. 74. Bogor, Indonesia. World Agroforestry Centre.

Titles in the Working Paper Series aim to disseminate interim results on agroforestry research and practices and stimulate feedback from the scientific community. Other publication series from the World Agroforestry Centre include: Agroforestry Perspectives, Technical Manuals and Occasional Papers.

Published by

World Agroforestry Centre

Southeast Asia Regional Office

PO Box 161, Bogor 16001, Indonesia

Tel: +62 2518625415

Fax: +62 2518625416

Email: icraf-indonesia@cgiar.org

Internet: http://www.worldagroforestrycentre.org/sea

(c) World Agroforestry Centre 2008

Working Paper nr 74

The views expressed in this publication are those of the author(s) and not necessarily those of the World Agroforestry Centre.

Articles appearing in this publication may be quoted or reproduced without charge, provided the source is acknowledged.

All images remain the sole property of their source and may not be used for any purpose without written permission of the source.

\section{Disclaimer for copyright page:}

The World Agroforestry Centre (ICRAF) is the international leader in the science and practice of integrating 'working trees' on small farms and in rural landscapes. The Centre invigorated the ancient practice of growing trees on farms, using innovative science for development to transform lives and landscapes. ICRAF is one of the 15 centres supported by the Consultative Group on International Agricultural Research (CGIAR).

The Conservation International (CI) is a non-profit international organization that seeks to protect earth's biodiversity hotspots and high-biodiversity wilderness areas around the globe. Its mission is to conserve the earths living natural heritage, global biodiversity and to demonstrate that human societies are able to live harmoniously with nature. 


\section{Abstract}

Addressing the need to develop techniques that help set area targets for species requiring landscape management has been the heart of collaboration between Conservation International (CI) and World Agroforestry Centre (ICRAF) in the Philippines. This initiative falls within the broader context of the Hotspot Alliance between the two global organizations, which aim to promote advances in the science and practice of agroforestry to improve human livelihoods and biodiversity conservation in Global Biodiversity Hotspots.

Apart of the scientific collaboration is a meeting-workshop to discuss the contribution of the agroforestry/ agricultural matrix to the conservation of globally threatened landscape level conservation in the Philippine Hotspots: moving from theory to practice. The meetingworkshop was held in Los Baños, Laguna, Philippines, April 11-12, 2008. This report covers the summaries of all presentations, a synthesis of the meeting-workshop and the current research gaps and issues identified in the conservation of globally threatened species requiring landscape level approach. Research needs and opportunities emerging from the workshops are shared in this report.

\section{Keywords:}

Landscape scale conservation, agroforestry, area demanding threatened species, Philippine Eagle, Eastern Mindanao Range, Sierra Madre Range 


\section{Acknowledgements}

We gratefully acknowledge the participants of this meeting-workshop for their interest and discussion. We also acknowledge the generous financial support of the Hotspot Alliance and the assistance particularly of Ms. Rafaela Jane Delfino and Ms. Desiree Boulanger. 


\section{Contents}

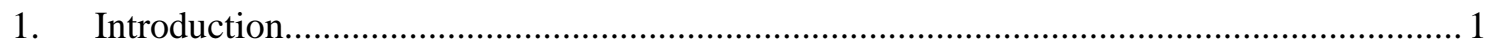

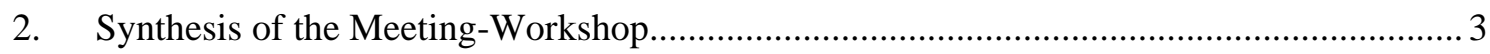

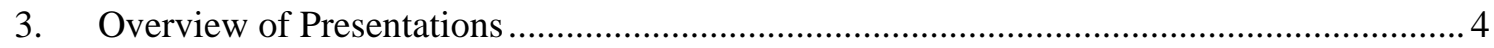

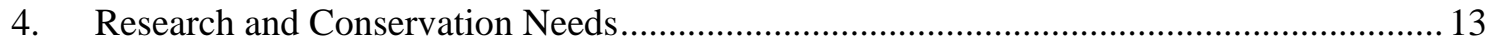

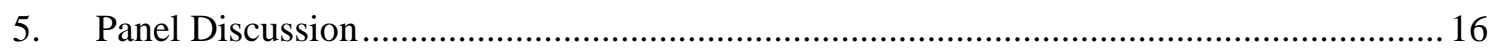

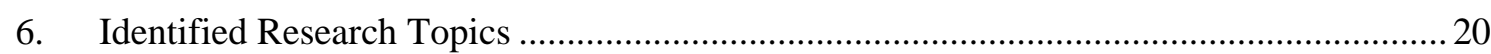

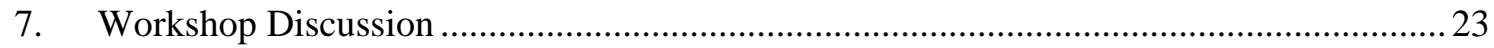

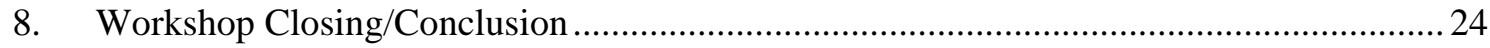

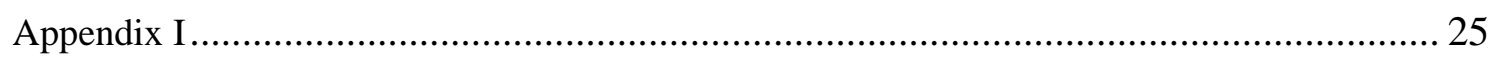

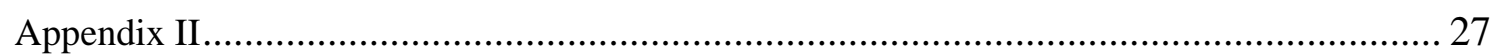

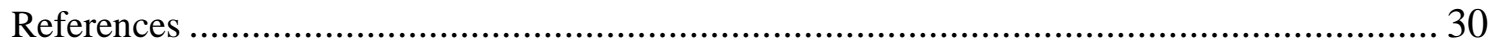




\section{Abbreviations}

ACB

ADTS

ASEAN

BFAR

BOI

CBD

CI

CITES

CVPED

DENR

DOE

DOST

FFI

FLUPs

GMO

GPS

ICRAF

IEC

IRR

IUCN

KBAs

LGU

LUPA

MEA

MKAVI

NCIP

NGOs

NIA

NIPAS

NPC
ASEAN Centre for Biodiversity

Area demanding threatened species

Association of South East Asian Nations

Bureau of Fisheries and Aquatic Resources

Board of Investments

Convention on Biological Diversity

Conservation International

Convention on International Trade in Endangered Species

Cagayan Valley Program on Environmental Development

Department of Environment and Natural Resources

Department of Energy

Department of Science and Technology

Flora and Fauna International

Forest Land Use Plans

Genetically modified organisms

Global positioning system

World Agroforestry Centre

Information and education campaign

Implementing rules and regulations

International Union for Conservation of Nature

Key Biodiversity Areas

Local Government Unit

Luwasnon Kag Malambuon nga Umahan Kag Kinaiyahan

Millennium Ecosystem Assessment

Mt. Kitanglad Agri-Venture Incorporated

National Commission on Indigenous People

Non-government organizations

National Irrigation Authority

National Integrated Protected Areas System

National Power Corporation

Pangabuhian para sa Arakenos 
PAWB Protected Areas and Wildlife Bureau

PCARRD Philippine Council for Agriculture and Natural Resources Research and Development

PECH Philippine Eagle Critical Habitats

PEF Philippine Eagle Foundation

PES Payments for environmental services

PICOP Paper Industries Corporation of the Philippines

RAMSAR Ramsar Convention on Wetlands

UNFCCC United Nations Framework Convention on Climate Change

UPLB University of the Philippines Los Baños

UPM University of the Philippines Mindanao 


\section{Introduction}

Single protected areas are insufficient to safeguard all species. Some globally threatened species that occur naturally in very low densities or move over large areas not only require a combination of sites but also require conservation action in the wider landscape where these sites occur. Conserving biodiversity while sustaining agricultural productivity, indigenous cultures, and rural livelihoods, requires new approaches or techniques to conservation (Harvey et al, 2008).

Addressing the need to develop techniques that help set area targets for species requiring landscape management has been the heart of collaboration between Conservation International (CI) and World Agroforestry Centre (ICRAF) in the Philippines. This initiative falls within the broader context of the Hotspot Alliance between the two global organizations, which aim to promote biodiversity conservation in Global Biodiversity Hotspots and advances in the science and practice of agroforestry to improve human livelihoods, respectively. The dual roles of agroforestry in contributing to the conservation of wild species in human-modified landscapes, and local livelihoods are increasingly being documented and recognized. The Hotspot Alliance was designed to explore this multifunctional nature by drawing on the respective expertise of $\mathrm{CI}$ in the science of safeguarding species and their habitat, and that of ICRAF in improving the productivity and sustainability of agricultural landscapes through agroforestry.

After a year of scientific collaboration, a solid GIS-based technique for modeling the area, connectivity, and land cover requirements of those threatened species in the Philippines that require landscape-level conservation has been developed. At the same time, methods for setting watershed management targets where Key Biodiversity Areas (KBAs) host species threatened by changing hydrological processes in the Philippines have been established. The products of this flourishing scientific collaboration have been presented in several national and international conservation society meetings and are currently being published. Building on these scientific advances, this research project is proposing to test in a much larger scale, to maintain the scientific advances of the work, and to move its findings from theory to practice.

To move ahead, a two-day meeting-workshop was conducted in Los Baños, Laguna Philippines on "Setting landscape conservation targets and promoting them through compatible land use in the Philippines" on 11-12 April. The meeting-workshop was convened to discuss the contributions of the agroforestry/agricultural matrix to the conservation of globally threatened landscape level conservation in the Philippines. Participants represented the public and private sectors, academe and conservation organizations.

The meeting-workshop responded to the need of a wider approach of conservation since the scales of conservation vary. It highlighted the science of area-demanding species and the critical ecological processes. Because of this scientific development, conservation scientists and practitioners were challenged by the following questions: 
a. Science - What level of land use intensity can maintain biodiversity? Populations and ranges of area-demanding threatened species? Drivers of threats to critical ecological processes? What are the needs for habitat restoration? What about climate change?

b. Implementation - How can land use be economically optimized while maintaining biodiversity? What landscape level action, and where, would deliver the greatest returnon-investment for biodiversity? What roles can different sectors play in these? What about opportunity costs? Payments for environmental services? 


\section{Synthesis of the Meeting-Workshop}

The meeting-workshop started with a series of presentations that focused on the importance of conservation at landscape level. A new approach to define landscape conservation targets based on species needs, as results from the CI-ICRAF cooperation became the highlight of the presentations. The approach is a GIS-based technique for modeling the area, connectivity, and land cover requirements of those threatened species in the Philippines. The approach utilized the criteria under which threatened species were evaluated on the IUCN Red List to derive spatially explicit targets.

Then, working group discussions followed and highlighted knowledge gaps and research needs on three major sets of issues for conserving threatened species at the scale of whole landscapes. A 'species science' group emphasized the relative lack of information about demography, distribution, and population dynamics of area-demanding threatened species in the Philippines, and the need to better quantify habitat use and suitability for improved landscape-scale decisions. The second group reflected on the implications of land use and global change on landscape ecosystem processes upon which biodiversity depends in the Philippine context. The third group identified areas related to key land- use trends where policies do and can have a significant influence on landscape conservation. The discussions also provided fertile ground for several exciting possibilities for leveraging the success of the project and fundraising on a larger scale. Priority proposals included satellite telemetry research for better understanding the needs of area-demanding species, restoration of widespread Imperata grasslands for biodiversity, carbon and livelihoods, as well as policy research to advise on the rapid biofuel development taking place in the Philippines.

A panel discussion with representatives from public and private sectors was conducted to address how landscape scale conservation activities and projects fit into their regional development agenda.

At the end, four main aspects were highlighted emerging from the two-day event in moving towards prioritizing areas for multiple benefits of agroforestry expansion: 1) meeting the needs of area-demanding threatened species (e.g. Philippine Eagle) that require landscape scale conservation; 2) addressing the maintenance of hydrological processes; 3) getting in front of emerging economic and policy trends; and 4) capacity building for landscape management and institutional arrangements at the appropriate scale. 


\title{
3. Overview of Presentations
}

\author{
Presentation 1: The CI-ICRAF Hotspot Alliance: science-based collaboration for human \\ livelihoods and biodiversity conservation in global hotspots Jean- \\ Marc Boffa, World Agroforestry Centre (ICRAF) Kenya
}

The conservation community has traditionally emphasized conservation of biodiversity through the protection of natural areas. About $10 \%$ of land is now officially designated as Protected Areas. However, it is now widely acknowledged that this is not sufficient to maintain critical habitat for species and ecosystem services. Because it tends to drastically modify its original environment, agriculture has been seen as having little value for conservation. However, with current trends of population growth and increases in global demand for food and resources, agriculture has come into sharper focus for simultaneously addressing poverty and meeting world food supplies, as well as conserving biodiversity and maintaining other critical environmental services. This is reflected in a number of recent global assessments (2008 World Development Report, MEA, IAASTD). The agricultural sector is faced with the two concurrent imperatives of 1) responding to the growing and diversifying demand for food, fiber, water, biomass for forage, fuel, and at the same time 2) supplying and maintaining ecosystem functions, and contributing to the reduction of pressures on natural forest, range, and aquatic ecosystems. In a context where natural forests are declining, agroforestry represents one of the promising $R \& D$ approaches for addressing and integrating both production and environmental conservation priorities. For the rural poor, trees can serve as farm assets, sustain and complement the productivity of associated crops and livestock, and provide marketable products. Agroforestry also enhances the productivity and sustainability of agricultural landscapes and contributes to the supply of ecosystem services, particularly the conservation of biodiversity, water, soil health, and carbon sequestration.

Drawing on their respective expertise in the science of safeguarding species and their habitat, and integrating trees on farms and landscapes for improving rural livelihoods, Conservation International and the World Agroforestry Centre have joined forces in the Hotspot Alliance. This global research collaboration seeks to promote advances in the science and practice of agroforestry to improve livelihoods and biodiversity conservation in Global Biodiversity Hotspots. The Alliance supports scientific studies, capacity strengthening and advocacy to support improved landscape-level management of species habitat, secure local livelihoods, as well as resilience of biodiversity and people to climate change. Pilot activities are conducted in the following areas:

- Alternative livelihood activities and orangutan conservation in Batang Toru, North Sumatra

- $\quad$ Livelihoods assessment in the Mantadia Biodiversity Corridor Restoration and Conservation Carbon Project, Madagascar

- Identification of landscape management targets for biodiversity conservation in the Philippines (which provides the focus of this workshop) 


\title{
Presentation 2: Contributions of agroforestry to landscape scale conservation - a global perspective
}

\author{
Goetz Schroth, CI-Conservation Strategies Division
}

The presentation attempts to answer the following questions: How can we conserve forests and their biodiversity and ecosystem services while providing livelihood opportunities for local people in landscapes whose economies and livelihoods depend on agricultural production? What are the biological-technical, institutional, and market frameworks that motivate and reward communities for maintaining and restoring functioning forest landscapes?

Not only natural forests provide habitat and forest ecosystem functions. Traditional shaded cocoa plantations (cabrucas) in the surroundings of the Una Biological Reserve in Bahia, Brazil have been shown to harbor endangered species of forest fauna and many rare tree species, as have shade coffee farms in Mexico. In Batang Toru, North Sumatra, orangutans venture several kilometers from the nearest forest into managed rubber agroforests to feed on durian trees. Where such agroforests occur on a significant spatial scale, why do we still need natural forest? There are at least three reasons: 1) Agroforests do not provide suitable habitat for all species. Research in high-diversity agroforests (cabruca, shaded coffee, jungle rubber, etc.) has consistently shown that even where total species richness in agroforests approaches that of natural habitat, certain species groups are typically underrepresented or missing in agroforests (e.g. understory fauna, tree regeneration). Therefore, natural habitat is necessary to maintain the full set of species in production landscapes. 2) Even high-quality agroforests depend on natural forest as source habitat for many species. Research comparing cocoa agroforests in landscapes with little natural forest (Ilheus; 5 percent) or much natural forest (Una; >50 percent) in Bahia, Brazil, has shown that these agroforests lose species as the natural forest cover in the landscape matrix decreases. 3) Throughout the tropics, traditional agroforests are under threat of intensification or even conversion owing to their low productivity. Relying on agroforests alone for biodiversity conservation would thus be ineffective for some species and very risky for many others.

Turning the question around, since we need natural habitat anyway, why does then the type of land use in the agricultural "matrix" matter for biodiversity conservation in production landscapes? Why promote high-diversity agroforestry and other conservation friendly land uses? First, because they provide habitat for many species, including endangered ones, for which available forest habitat may not be sufficient. Second, because they ensure connectivity throughout the landscape, without which species populations in small forest fragments may not be viable on the long term. For example, even small forest fragments in the Una area would not retain their almost complete set of forest fauna species without the connecting matrix of cabrucas.

The task of conserving biodiversity in production landscapes is thus two-fold: 1) to protect forest and other natural habitat in the landscape from conversion, also into agroforests, and 2) to promote land use practices in the agricultural matrix that meet human needs in terms of productivity and sustainability and that are sufficiently biodiversity-friendly to provide connectivity and additional habitat for threatened species. Promoting such comprehensive landscape strategies requires the integration of interventions at several levels: 1) 
technical/biological, 2) institutional, and 3) market related. The presentation gives several examples of such integrated approaches.

\title{
Presentation 3: Agroforestry Systems and Grassland Rehabilitation
}

\section{Rodel D. Lasco, ICRAF Philippines}

Over the years, the Philippines' forest resources degenerated because of massive logging activities, fuel wood gathering and charcoal making, shifting cultivation and permanent agriculture. At the beginning of the 20th century, 70 percent of the total land area (21 million ha) was covered with lush forests. Now, only 20 percent of land is with forests while millions of hectares of grasslands mainly Imperata cylindrica lie largely unproductive and environmentally destructive. The government has been trying vainly for the last 100 years to rehabilitate these grasslands with little success.

Agroforestry which involves combining agricultural crops and trees offer a great a potential for the rehabilitating grassland areas. Imperata is not very tolerant of shade, but will quickly germinate in the open. The main requirement of a cropping system is that it provides a closed canopy most of the time and is sufficiently dense to suppress individual Imperata plants. There are number of agroforestry options for grassland rehabilitation including planting of fast growing trees, multistory systems (e.g. rubber-based systems), and assisted natural regeneration.

\section{Presentation 4: Ecology and conservation status of the Philippine Eagle, a species in need of landscape scale conservation}

\author{
Todd Katzner, National Aviary, USA; Jayson Ibanez, Philippine Eagle \\ Foundation; Nigel Collar, Birdlife International, UK
}

The Philippine Eagle (Pithecophaga jefferyi) is one of the world's rarest birds of prey and deeply in need of conservation action. Here we describe the known ecology of the species, evaluate threats it faces, construct a simple demographic model to explore its population status, and by comparison with other island eagles, identify future directions for research on this rare species.

Philippine Eagles were distributed throughout the largest Philippine islands. Their current range is much reduced due to a variety of human-driven influences and the current population is estimated to be between 200 and 500 individuals. Although Mindanao populations have been well studied, the greatest gaps in knowledge of the species are on Luzon, Samar and Leyte.

Philippine Eagles are long-lived, monogamous, highly faithful to their territories, and have a 20 -month nesting cycle. At present Mindanao populations produce $\sim 0.3$ chicks/pair/year, meaning that in 10 years of breeding, a single pair fledges 3 chicks. If we estimate that 33 percent of juveniles survive to adulthood (this would be a high rate for most similar eagles) then 1 chick survives for every 10 years of eagle breeding. This means that a Philippine Eagle pair must breed for 20 years just to replace itself (i.e., for the population to remain stable). This requires that each breeding eagle live to at least 27 years of age, meaning 95 percent annual adult survival rates. It is important to consider whether this is occurring today. 
The diet of Philippine Eagles has only been studied at a few nests on Mindanao where birds eat primarily medium-sized mammals, especially the flying lemur, palm civet, flying squirrel, and monkeys. Eagle nests are located in primary dipterocarp forest, habitat that currently is highly fragmented. The majority of known nests are on forest edge, although there may be other unknown nests in the forest interior. Nest trees are always large but not always emergent, as is the case for some other similar species. A few birds have been tracked with radio telemetry and those birds were often found near forest edge and traveled long distances over disturbed habitat to reach foraging sites. All these characteristics make the species vulnerable to effects of habitat fragmentation.

The Philippine Eagle is listed as critically endangered on the IUCN Red List and by the Philippine Government. A variety of factors destroy the species' habitat, especially forestry, mining and agriculture and all occur inside and outside of protected areas and even adjacent to eagle nests. Only five percent of primary Philippine forest remains, compared to what existed 200 years ago. Other threats eagles face include shooting, poisoning, and electrocution, competition with humans for prey, demographic instability, disease, scientific and public ignorance of the species, and, critically, the difficulty researchers have in obtaining government permits to study the bird. All these factors except the last also impact Golden Eagles living in the British Isles; lessening mortality rates have been identified as critical to British eagle conservation.

To conserve the Philippine Eagle, we must address a number of factors that threaten its persistence, especially mortality rates, habitat loss and habitat fragmentation. Conservation action must occur throughout the range of the species and at the appropriate (landscape) scale. Research must be conducted to identify the most appropriate actions and it is critical and urgent that appropriate permits be granted in a timely manner for this research. Failure to take these steps will result in the extinction of this emblematic species.

\section{Presentation 5: A new approach to define landscape conservation targets based on species needs - results from the CI-ICRAF cooperation}

Karl L. Villegas, Leiden University-Isabela State University; and Grace B. Villamor, ICRAF Philippines

The Philippines is facing a crisis of biodiversity, with extensive deforestation driving species extinctions. In many cases, these extinctions can be averted by site level strategies protecting the key biodiversity areas where threatened species occur. However, some threatened species range widely over the landscape, and others depend on the maintenance of landscape level ecological processes to allow their persistence at particular sites. Methods for targeting biodiversity conservation in such situations are in their infancy. Here, we develop methods for doing this, and test these with two Philippine case studies: the area-demanding Philippine Eagle (Pithecophaga jefferyi) and the hydrological processes necessary to maintain the threatened species of Agusan Marsh. For P. jefferyi we use the criteria under which it is evaluated on the IUCN Red List to derive spatially explicit targets. This reveals that land management modifications to allow the recovery of the species' populations to maximum population density and occupancy throughout suitable habitat in Eastern Mindanao (11,346 $\mathrm{km} 2)$ or the Sierra Madre (13,786 km2) would - just - be sufficient for it to be downlisted from the IUCN Red List. For Agusan Marsh we show that reduction of impact on 
hydrological processes is necessary over an area of 8,993 $\mathrm{km} 2$ of its drainage basin, in order to allow the persistence of the site's threatened species. Further work is necessary to develop equivalent methods for targeting other ecological processes on which threatened species depend, for landscape level adaptation to climate change, and for optimizing land use planning to deliver maximum socio-economic benefits without compromising biodiversity. Nevertheless, the techniques developed here should allow explicit, justifiable targeting of landscape management and conservation of biodiversity in the Philippines and beyond.

\section{Presentation 6: The Cagayan Valley Program on Environment and Development and research on landscape level conservation in the Sierra Madre Range Merlijn van Weerd, CVPED, the Netherlands}

The Cagayan Valley Program on Environment and Development (CVPED) is, since 1989, the academic partnership of the College of Forestry and Environmental Management (CFEM) of Isabela State University (ISU) in the Philippines and the Institute of Environmental Sciences (CML) of Leiden University in the Netherlands. CVPED has an office with a library, working desks, computer facilities and internet on the ISU campus in the town of Cabagan. CVPED's main task is to host and coordinate undergraduate, graduate and PhD studies on environmental issues in Cagayan Valley and the Sierra Madre Mountain Range. Students are mainly from the partnership universities in the Philippines and the Netherlands but other students and visiting scientists are welcome as well. Two strategic multidisciplinary research themes are being pursued:

1. The drivers and dynamics of land use change and its impact on biodiversity; and

2. Natural resource management and biodiversity conservation (co-management)

Past and current studies deal with:

- Water and food in Northeast Luzon (starting; three PhD students: Karl Villegas, Willie Saliling, Miladis Afidchao)

- Community participation in biodiversity conservation: Philippine crocodile conservation in San Mariano (ongoing; PhD research Jan van der Ploeg)

- The Agta Indigenous People and Tropical Rainforest Management in the Northern Sierra Madre Natural Park, Luzon, the Philippines (ongoing, PhD research Tessa Minter)

- Biodiversity and conservation in the Northern Sierra Madre Natural Park, Luzon, the Philippines (ongoing; $\mathrm{PhD}$ research Merlijn van Weerd)

- The adoption of agroforestry in the foothills of the Sierra Madre (ongoing; coordinated by Dr. Denyse Snelder)

- $\quad$ Forest patches in Northeast Luzon: their status, role and perspectives for conservation in integrated land-use systems (several articles; coordinated by Dr. Denyse Snelder)

- $\quad$ Land use potentials on Imperata grasslands in Northeast Luzon (several articles; coordinated by Dr. Denyse Snelder

- $\quad$ Linking process and pattern of land use change: illustrated with a case study in San Mariano, Isabela, Philippines (2006; PhD thesis Koen Overmars) 
- Investing in the land: agricultural transition towards sustainable land use in the Philippines forest fringe (2006; PhD thesis Marino Romero).

- $\quad$ Resource management in ancestral lands: the Bugkalots in north-eastern Luzon (2004; $\mathrm{PhD}$ thesis Dante Aquino)

- The social dynamics of deforestation in the Sierra Madre, Philippines (1998; PhD thesis Gerhard van den Top)

CVPED's research history, expertise and local experience could be beneficial for an applied research project on land use and landscape conservation for globally threatened species in northern Luzon in partnership with CI, ICRAF and other stakeholders. More information on http://www.leidenuniv.nl/cml/pmo/index.html and www.cvped.org.

\title{
Presentation 7: Landscape level conservation and the Philippine Eagle in the Sierra Madre Range
}

\author{
Mariano Roy M. Duya, Sierra Madre Biodiversity Corridor Conservation \\ International Philippines
}

Despite numerous reported sightings of the Philippine Eagle in the Sierra Madre mountains of Luzon Island, there has been little scientific data collected on the biology of this majestic bird (nest distribution, prey, etc.) in the island simply because no nest has yet been documented in the area. The lack of scientific data is a critical gap that must be filled if we hope to prevent the extinction of this species. Population studies in Luzon, which falls under a different faunal region than the other islands on which the Philippine Eagle also occurs, are important for the development and implementation of a protection and conservation program for the eagle's entire population. Baseline information, including the ecological needs of the species as well as the reasons for population decline, is important for formulating sound conservation decisions and plans.

The Philippine Eagle project in the Sierra Madre was initiated in 2002 to 2004 through a funding support from the Critical Ecosystem Partnership Fund (CEPF) that aims to verify reported sightings and locate nesting areas of the species to conduct research on the biology and ecology of the species. The current project is funded by the Keidanren Nature Conservation Fund (KNCF), the main targets of the program are: 1) ground validation and verification on the reported Philippine Eagle sightings in Cagayan, Quirino, Nueva Vizcaya, and Aurora province; 2) research study on the Philippine Eagle found along the Sierra Madre Mountains (e.g. feeding ecology b. breeding behavior c. prey base density); 3) conservation and awareness campaign on the importance of the Phil. Eagle and its habitat; and 4) capability building efforts for local stakeholders.

From 2002-2006, a total of seven retrieval incidences of Philippine Eagle had been recorded. Snare for wild pig and deer was the common mode of capture. Between 2004 and 2006, a total of 17 surveys had been conducted. A total of six confirmed sightings of the species were recorded that includes two sites with a pair of Philippine Eagle. The survey also observed two juveniles in 2 sites both in the months of March and April. Distribution of Philippine eagle sightings was already mapped out. 
A perception survey has been conducted recently in the area with the local people. Initial analysis suggested the following:

1. Majority of the respondents have not seen Philippines Eagle and not aware of the species status;

2. Most of the respondents are aware that the forest cover including wild animals are declining; and

3. The respondents are also willing to support any conservation projects in their community.

\title{
Presentation 8: Establishment of Philippine Eagle critical habitats: Towards the Long Term Preservation of the Philippine Eagles and Protecting Watersheds
}

\author{
Angelito A. Cereño; J.C. Ibañez; D.I. Salvador; and H. Carig, Philippine \\ Eagle Foundation
}

The Philippine Eagle is one of the largest eagles and most critically endangered species among birds of prey in the world (Birdlife International 2007). This species is endemic to the Philippine archipelago and is geographically known to occur in the islands of Luzon, Samar, Leyte, and Mindanao. Their population is threatened by hunting and continuing loss of its habitat through logging, timber poaching and shifting cultivation. The status of the Philippine Eagles makes the species important for conservation at a global scale. At a national scale, the Republic Act 9147 enacted in 2001, otherwise known as the Wildlife Resources Conservation and Protection Act sets the conservation and the long term survival of the Philippine Eagles not just a priority but a mandate.

Along this line, the Philippine Eagle Foundation spearheaded the establishment of Philippine Eagle Critical Habitats (PECH) within the Eastern Mindanao Biodiversity Corridor. The primary goal of the project is to secure the forests to protect the Philippine Eagle nesting territories and help ensure the species' long term survival. In addition, protecting the Philippine eagle habitat serves as an umbrella protection for all other wildlife inhabiting within it including human that depend on the forest for their survival. Furthermore, the PECH is a habitat management scheme that protects the integrity of watersheds for its ecological services.

Using the minimum known ecological requirement for the Philippine eagle breeding pair and having known the species' high fidelity on its occupied territory, a 7,000-hectare of forests around the nest tree has been delineated and declared critical habitat through an ordinance enacted by the local government unit (LGU). With this scheme, seven (7) Philippine eagle nesting sites have been declared critical habitats from March 2005 to April 2008 situated in the provinces of Davao Oriental, Compostela Valley and Surigao del Sur - all in Eastern Mindanao. A site-specific community-based management plan was developed as a manual in institutionalizing habitat protection and other management interventions into the development plan of each local government unit. Furthermore, a memorandum of agreement was executed between and among national line agencies, LGUs and other stakeholders for their support and involvement in the conservation and management of these critical habitats. However, more advocacy work and further studies on its effectiveness are needed. 


\section{Presentation 9: Landscape conservation - How do we achieve the targets? The case of Manupali Watershed}

\section{Delia Catacutan, ICRAF-Philippines}

The ICRAF's research and development framework and innovations for Manupali watershed in Latapan, Bukidnon have been shared. The presentation was divided into three phases. Phase 1 is about the technical innovations of agroforestry e.g. natural vegetative strips or NVS were farmers in the area adopted. NVS has been identified as a soil erosion barrier as now a common practice and evolved to become an agroforestry system in the sloping lands. Phase 2 is about the institutional innovations. Here, a local government-led NRM plan was initiated and became the main output. Aside from that, activities on the farm and community level have been conducted and formed Landcare associations and agroforestry tree-seed associations.

In spite of this activities, key drivers of land use change have been impacted the activities, such as population increase, emergence of corporate farming and other agribusiness, national policy direction (e.g., designating the province as a grain and high value vegetable production area), provincial development initiatives (e.g., sugar milling, feed milling etc.) and introduction of new farming technologies.

Because of these, new issues and challenges are raised, these are:

- How can agroforestry be a more attractive option to farmers—value adding?

- What viable mechanisms can sustain/enhance adoption of conservation practices?

- What kinds of support are most needed at the local and national levels and from communities outside the watershed?

Phase 3 is currently on-going and it is about deepening the technical knowledge of vegetableagroforestry (VAF) system and incentive-based policies to: a) promote VAF system, and b) reward environmental services. Here, issues raised are explored to answer through the following activities:

- Deepening knowledge-base on the technical viability of tree integration in vegetable production systems (on-farm research);

- Identifying market niches of farm-grown trees and high-quality vegetables;

- Policy-action research on institutional arrangements for promoting VAF and rewarding environmental services; and

- $\quad$ Tools testing for spatial, hydrological and carbon-stock assessments.

\section{Presentation 10: Integrating livelihoods and multiple biodiversity values in landscape mosaics based on the CIFOR-ICRAF Landscape Mosaic Project}

Jean-Marc Boffa, World Agroforestry Centre (ICRAF) Kenya

Forest conversion and fragmentation in landscapes of high global biodiversity value often result in mosaics of various land uses including crop fields, pastures, agroforests, plantations, and natural forests in various degrees of use and protection. These areas often overlap with high poverty incidence and support a diverse array of rural livelihoods. Biodiversity 
conservation in these landscapes increasingly recognizes the importance forest patches and trees in the matrix. Yet there is limited knowledge about how land cover patterns and land use changes influence the viability of species of local and global importance. Successful integrated management of landscapes for both livelihoods and conservation requires reconciliation of multiple local and global biodiversity values in land use and conservation planning.

The CIFOR-ICRAF Joint Biodiversity Platform promotes a vision of multifunctional landscapes that support both sustainable rural livelihoods and biodiversity conservation. The Platform implements the Landscape Mosaics Project which aims at catalyzing participatory action research that integrates sustainable livelihoods and biodiversity conservation objectives into land use planning processes in five tropical landscape mosaics through appropriate R\&D approaches and instruments. Sites include East Usambaras in Tanzania, Manompana in Madagascar, Takamanda-Mone in Cameroon, Jambi in Sumatra and Luang Prabang in Laos.

The Landscape Mosaics Project adopts a multi-layered approach based on a comparative assessment of:

- landscape patterns, dynamics of land use change and how they influence the persistence of key groups of species,

- local and external values, and traditional knowledge related to biodiversity,

- $\quad$ traditional and formal regulatory frameworks and how they affect resource management as well as support to multistakeholder definition and negotiation of multifunctional landscape scenarios that aim to:

- integrate local priorities and knowledge,

- $\quad$ enhance the contribution of tree-based options for landscape connectivity and conservation,

- $\quad$ recognize legal pluralism in regulating resource access and management, and

- $\quad$ reward communities for conservation services. 


\section{Research and Conservation Needs}

Based on the presentations, research and conservation implementation needs and priorities to meet the targets emerging from the project were identified according to three main topics as arranged in tables below.

I. Landscape level conservation of the Philippine Eagle, an area-demanding threatened species

\begin{tabular}{|c|c|c|}
\hline Issues and Problems & Research Gaps & Potential Partners \\
\hline $\begin{array}{l}\text { 1. Distribution and } \\
\text { abundance of Philippine } \\
\text { Eagle; and habitat } \\
\text { conditions and } \\
\text { requirements }\end{array}$ & $\begin{array}{l}\text { - distribution and abundance } \\
\text { in Luzon and Visayas } \\
\text { Islands using telemetry and } \\
\text { GPS } \\
\text { - suitable habitat analysis } \\
\text { and modeling } \\
\\
\text { - impact of habitat } \\
\text { fragmentation }\end{array}$ & $\begin{array}{l}\text { - } \\
\text { CEMIX (private funding } \\
\text { partner for equipment); } \\
\text { Peregrine Fund; National } \\
\text { Aviary } \\
\text { - } \quad \text { PEF; DENR (particularly } \\
\text { the permit issues and } \\
\text { retrieval of captured } \\
\text { eagles) } \\
\text { - } \quad \text { ICRAF; UP Mindanano; } \\
\text { UP Los Baños }\end{array}$ \\
\hline 2. Mortality studies & $\begin{array}{l}\text { - mark-recaptured studies } \\
\text { - studies on diseases } \\
\text { - DNA sequencing }\end{array}$ & $\begin{array}{ll}\text { - } & \text { Technical support of } \\
& \text { Peregrine Fund \& } \\
& \text { National Aviary } \\
\text { - } & \text { DENR \& PEF: } \\
\text { particularly on blanket } \\
\text { - } & \text { UP Mindanao \& UPLB }\end{array}$ \\
\hline $\begin{array}{l}\text { 3. Studies of other area- } \\
\text { demanding threatened- } \\
\text { species (ADTS) * }\end{array}$ & $\begin{array}{l}\text { - Flying foxes } \\
\text { - Tamaraw } \\
\text { - Hornbills } \\
\text { - Imperial pigeons } \\
\text { - Philippine Cockatoo } \\
\text { - Large Raptors } \\
\text { - Giant soft-shelled turtle } \\
\text { - Marine turtles } \\
\text { - Green-tailed parrot finch }\end{array}$ & $\begin{array}{ll}\text { - } & \text { Bat Count (Philippines); } \\
& \text { CI-Phil } \\
\text { - } & \text { DENR } \\
\text { - } & \text { PESCP; FFI } \\
\text { - } & \text { KATALA Foundation }\end{array}$ \\
\hline $\begin{array}{l}\text { 4. } \\
\text { Testing the benefits of } \\
\text { various agroforestry } \\
\text { systems to other ADTS }\end{array}$ & $\begin{array}{l}\text { - Identifying and predicting } \\
\text { land use patterns of ADTS } \\
\text { on agroforestry systems }\end{array}$ & $\begin{array}{l}\text { ICRAF; PEF; UP } \\
\text { Mindanao; DENR }\end{array}$ \\
\hline
\end{tabular}

*Whether these species have commonalities such as:

1. K- selection species

2. Species dependent spatially and temporally variable resources 
Key challenges:

- Difference of densities (based on the information collected): For example, Mindanao (large size habitat) vs. Samar and Leyte Islands (smaller size of habitats)

- Available information of habitats. There is lack of habitat information as well as satellite telemetry studies in Luzon as compared to Mindanao.

- Available rehabilitation centers. Only one rehabilitation center in Luzon (Los Baños).

\section{Conserving landscape ecosystem processes on which biodiversity depends}

\begin{tabular}{|c|c|c|}
\hline Issues and Problems & Research Gaps & Potential Partners \\
\hline $\begin{array}{l}\text { 1. Hydrological } \\
\text { - erosion/siltation and its } \\
\text { effect on species; } \\
\text { - decreasing waterflows in } \\
\text { watersheds; } \\
\text { - no valuation of watersheds } \\
\text { (in terms of biodiversity) } \\
\text { - limited data for } \\
\text { hydrological assessment } \\
\text { - water users allocation } \\
\text { (biodiversity needs) } \\
\text { - stakeholder network } \\
\text { (upstream and } \\
\text { downstream) }\end{array}$ & $\begin{array}{l}\text { - quantifying how } \\
\text { biodiversity affects } \\
\text { hydrology and vice versa } \\
\text { - which land use strategy } \\
\text { could restore water flow } \\
\text { and livelihoods } \\
\text { - (baseline) watershed study } \\
\text { for intervention purposes } \\
\text { - economic valuation of } \\
\text { water } \\
\text { - correlate landuse to } \\
\text { waterflow } \\
\text { - link water to biodiversity } \\
\text { - hydrological modeling, } \\
\text { even at coarse scale }\end{array}$ & $\begin{array}{l}\text { - LGUs, ICRAF, NPC, NIA } \\
\text { - MKAVI } \\
\text { - CI, Save Mindanao } \\
\text { - CI, ICRAF, LGU } \\
\text { - farmers beneficiaries } \\
\text { - Leiden University; Isabela } \\
\text { State University; \& Oxford } \\
\text { University }\end{array}$ \\
\hline $\begin{array}{l}\text { 2. Nutrient cycle/pollution } \\
\text { - effects of pollution to } \\
\text { biodiversity; } \\
\text { - lack of implementation on } \\
\text { enforcement of pollution } \\
\text { laws } \\
\text { - monitoring effect of } \\
\text { herbicides/pesticides } \\
\text { - Mining impact (e.g. } \\
\text { mercury) in Agusan Marsh } \\
\text { and Cagayan Valley } \\
\text { - studies of top-predator } \\
\text { species }\end{array}$ & $\begin{array}{l}\text { - Nutrient loading as an } \\
\text { indicator }\end{array}$ & - Mining companies \\
\hline $\begin{array}{l}\text { 3. Climate } \\
\text { - linkage of land use } \\
\text { systems and resilience to } \\
\text { extreme climatic events; } \\
\text { - greenhouse gas (GHG) } \\
\text { emissions from } \\
\text { deforestation and land use } \\
\text { change (carbon cycle) }\end{array}$ & $\begin{array}{l}\text { - microclimate change in the } \\
\text { affected area as related to } \\
\text { deforestation and } \\
\text { agricultural production } \\
\text { - lack of map to show } \\
\text { critical areas }\end{array}$ & $\begin{array}{l}\text { - CI, carbon buyers, ICRAF, } \\
\text { UPLB, LGUs }\end{array}$ \\
\hline
\end{tabular}

Fire and pollination factors were also considered as important research topics for landscape conservation approach. 
III. Context and policies affecting the landscape conservation

\begin{tabular}{|c|c|}
\hline Issues and Problems & Research Gaps \\
\hline $\begin{array}{l}\text { 1. With the passage of the Philippine } \\
\text { Biofuels Act, possible impacts are: } \\
\text { a. Loss of food production and } \\
\text { biodiversity; } \\
\text { b. Potential threat of biofuel production } \\
\text { on biodiversity e.g. Jatropha }\end{array}$ & $\begin{array}{l}\text { - Policy regulation on the scale of } \\
\text { investment and designation of appropriate } \\
\text { sites; } \\
\text { - Role of LGUs in biofuel investments; } \\
\text { - Social, economic, environmental impacts } \\
\text { of large-scale biofuel production }\end{array}$ \\
\hline $\begin{array}{l}\text { 2. Genetically modified organisms (GMO) } \\
\text { and/or invasive species threatens } \\
\text { biodiversity }\end{array}$ & $\begin{array}{l}\text { - Harmonization of policies regarding } \\
\text { biosafety and GMOs of concerned agencies }\end{array}$ \\
\hline $\begin{array}{l}\text { 3. } \begin{array}{l}\text { Mining activities affect } \\
\text { ecosystems/landscapes/biodiversity }\end{array} \\
\text { 4. Transboundary issues in landscape } \\
\text { conservation is not well understood }\end{array}$ & $\begin{array}{l}\text { - Overlapping powers/authorities between } \\
\text { national and local governments } \\
\text { (governance) }\end{array}$ \\
\hline $\begin{array}{l}\text { 5. Ecosystems approach is not yet widely } \\
\text { adopted by local governments: } \\
\text { political/administrative boundaries vs. } \\
\text { ecosystem boundaries }\end{array}$ & $\begin{array}{l}\text { - Develop and adopt landscape/ecosystems } \\
\text { approach to management }\end{array}$ \\
\hline 6. Outdated baseline of forest biodiversity & $\begin{array}{l}\text { - Investment for comprehensive monitoring } \\
\text { and assessments }\end{array}$ \\
\hline 7. Governance on environmental services & - Policies within the PES domain \\
\hline $\begin{array}{l}\text { 8. Impacts of climate change on } \\
\text { biodiversity }\end{array}$ & $\begin{array}{l}\text { - Policy on mitigation and adaptation } \\
\text { measures }\end{array}$ \\
\hline
\end{tabular}

Aside from the identified research gaps presented on the table, there are other issues raised related to global developments. These are:

- $\quad$ links to international conventions (e.g. CITES, RAMSAR, UNFCCC);

- biodiversity targets of the 2002 World Summit on Sustainable Development;

- Conference of Parties-Convention of Biological Diversity (COP-CBD) opportunities on ecosystems approach; and

- $\quad$ Article 8J- indigenous people and knowledge management. 


\section{Panel Discussion}

There are five panelists from different sectors. Each panelist was given five minutes to address the question: "How does landscape scale conservation fit into the regional development agendas?”

\section{Victor Adrian Pabilona, Mt. Kitanglad Agri-Venture Inc. (MKAVI)}

The climate has really changed in Bukidnon e.g. the planting cycle by the local farmers have reduced dramatically from three to one and a half, and this is primarily due to the decrease of water flow. Based on their observation, the buffer zones in the mountain ranges of Bukidnon, Kitanglad, Kanlaon and Galatungan have really been depleted if not cut. MKAVI could show pictures in their target areas as evidence. Because of these, all stakeholders including the business or private sector, LGUs, and community will have active roles to play. Especially the indigenous peoples would greatly help and would have positive impacts to all of their plans.

Currently, MKAVI through the Iliman Foundation has started with approximately 15,000 hectares to provide livelihoods to the families in the area as a support to our rehabilitation and reforestation projects. MKAVI is still studying on the potentials and/or the best models for this, and exploring how to integrate livestock and other products. They have expressed that they could benefit from the research of this group and could set these areas as one of the research targets. The data from this project would really be a great help for them to really reforest the mountains.

\section{Antonio Manila, Protected Areas and Wildlife Bureau (PAWB)-Department of Environment and Natural Resources (DENR)}

PAWB is mandated to undertake the habitat and the species conservation in collaboration with our partners e.g. non-government organizations (NGOs), LGUs and other concerned organizations. For landscape conservation, PAWB has two working groups. First, the ASEAN Working Group on Nature Conservation and Biodiversity, in which PAWB is working for about 10 years with the ASEAN Ministers of the Environment in the preservation of the ASEAN Heritage Parks. In the 2004-2010 work-plan the primary task is to promote the proper management and development of ASEAN Heritage Parks as a platform to promote the conservation parks. The focus areas will be the common conservation sites such as coral reefs and mountain ecosystems were there are threatened species. In the Philippines, two protected areas were included and promoted as ASEAN Heritage Parks namely, the Mt. Iglit-Baco National Park in Occidental Mindoro and the Mt. Apo Natural Park in Davao which covers Arakan in Mindanao, in recognition of the globally threatened Tamaraw and Philippine Eagle, respectively. Second, the ASEAN Centre for Biodiversity (ACB) which promotes and develops link with the public, private sector, civil society, international development institutions, and donor community for the sustainable use of biodiversity. In March 2008, a workshop on Management and Effectiveness Tools for ASEAN Heritage Parks and Protected Areas was conducted. 
The need for the landscape scale and biodiversity conservation has long been recommended by PAWB e.g. the six islands from the Philippines and three from Malaysia require landscape level approach. With this, meetings for a joint management between the Philippines and Malaysia are on going.

There are policies that address the landscape conservation. One is the Wildlife Act of 2001 or Republic Act No. 9147 (Act providing for the Conservation and Protection of Wildlife Resources and Their Habitats). The implementing rules and regulations (IRR) recognize the need for management of the area outside the protected areas that is needed to expand and extend for the management of habitat and the survival of threatened species. The very first critical habitat that was identified is the Las Pinas Critical Habitat Areas in Manila as a site for migratory birds. Proclamation No. 1412 allows the creation of the council to manage the critical habitat.

Another law is the National Integrated Protected Areas System or NIPAS Act (Republic Act No.7586). The law applies to practically all types of specially designated areas that require conservation or protection of natural habitats and threatened flora and fauna. One category that is related in this research is the protected landscape and seascape. This category refers to areas of national significance, which are characterized by the harmonious interaction of man and land while providing opportunities for public enjoyment through recreation and tourism within the normal lifestyle and economic activity of these areas.

Currently, DENR is in the process of identifying critical habitats and threatened species. There are eight proposed critical habitats in the Philippines, basically covering the Philippine Eagle sites and nesting grounds e.g. one in Bislig as dominated by Paper Industries Corporation of the Philippines (PICOP); two in Davao Oriental; and three networks of beaches along Zambales and Bataan as nesting habitat of turtles.

\section{Nilo Oponda, University of the Philippines Mindanao (UPM)}

He mentioned the positive and negative sides of soil and water conservation activities and other agroforestry systems and its impacts to the farmers in Mindanao. One of the reasons for its failures is the lack of continuous technical support.

As an academic institution, UP Mindanao recognizes students as assets for research. The link with other institutions like Philippine Eagle Foundation (PEF) contributes greatly in the research efforts. Among the researches with student and partnership involvement are: Biodiversity Assessments in Mt Nigitan; research activities in Agusan Marsh; Sagu Palm starch utilization for livelihood development; tissue culture and DNA sequencing of Sagu Palm; assessment of distribution of Sagu Palm in Mindanao; and suitability of Sagu Palm in various agroforestry systems.

\section{Leonardo Reovoca, Municipal Councilor of Arakan, Cotabato}

He shared the Municipal Ordinance No. 06-309 or known as an Ordinance Institutionalizing the Luwasnon Kag Malambuon nga Umahan Kag Kinaiyahan, Pangabuhian para sa Arakenos (LUPA Program) as the flagship program of the municipality for agriculture and environment. This ordinance is implemented with the following goals and objectives: 1 ) to ensure the 
sustainable growth of the agriculture sector giving emphasis on livelihood and food security; 2) to empower the primary actors and all other stakeholders of agriculture sector of the Municipality; 3) to protect the important natural resources of the Municipality from further degradation; 4) to improve watershed management, develop and restore wildlife habitat; and 5) to improve land tenure arrangement.

The LUPA program components are: institutional development; watershed management; agricultural productivity and income enhancement; research and extension mechanism improvement; market support system development; development planning and policy advocacy; land tenure improvement; basic social support services; and indigenous people development concerns.

The ordinance was implemented in July 2007. One of the focus projects is the rubber-based farming system. They have designed a system that allows multi-cropping. With the $2 \mathrm{mx} 3 \mathrm{mx}$ $21 \mathrm{~m}$ distance, staple food like dinorado rice, corn, and root crops can be planted together with rubber trees. The Municipal agriculturist is conducting this system in different areas of Arakan. Planting materials are provided to the farmers and spacing requirements must be complied.

One of the specific activities that the municipality would like to undergo is to conduct a delineation survey of Mts. Sinaka, Kabiko, and Kimambuli and if possible to have watershed assessment of the mountain ranges. The waterflow coming from Mt. Sinaka is contributing to Pulaman River towards Liguasan Marsh and to other parts of Davao City and towards the main Davao River.

To expedite the adoption of sustainable agricultural production systems and diversified farming systems among the farming communities in the municipality, there are three strategies identified: 1) appropriate technology generation and dissemination of biodynamic/organic farming, diversified farming, livestock and poultry integration, inland fish production; forest farming and alternative health; 2) demonstration and model farms; and 3) production and distribution of planting materials. The Municipality of Arakan is exploring ways to collaborate with PEF on their research efforts.

\section{Bien Dolom, Eco-Governance - ECOGOV (USAID-funded project)}

Under the DENR - EcoGov project, there are room for opportunities for small-grant projects. EcoGov is a technical assistance on forestry, costal resources and waste management projects and explore on partnership project between the LGUs and the national agencies. The project assists LGUs to develop partnership with DENR, Bureau of Fisheries and Aquatic Resources (BFAR), and National Commission for Indigenous People (NCIP), and other agencies. In addressing environmental management the approach is at landscape level. The project operates in four regions: Northern Luzon, Central Visayas, Western Mindanao and Southern Mindanao. These areas are strategically located and near the KBAs which was previously identified in the studies of CI and other NGOs. For instance, in Northern Luzon, the LGUs are nearby the Quirino Protected Landscape; and in Mindanao, KBAs such as the Saranggani seascape and Mt. Apo are found. The focus of assistance is concentrated with the LGUs. The project believes that the sustainability of the programs is ensured if the LGUs are directly involved on the program - since LGUs are the ones working with the communities. 
Biodiversity conservation initiatives will actually depend on the decisions of the local communities.

One of the specific assistances that EcoGov has provided is the formulation of Forest Land Use Plans (FLUPs) where biodiversity conservation objectives e.g. KBAs and ancestral domain claims are integrated in FLUPs. The objective of Forest Land Use Planning is to ensure that the forest lands have on-sight managers. Once the FLUPs have been formulated, the issuance of tenure instruments are facilitated initially through co-management with LGUs and later on with tenure instruments issued, EcoGov can provide assistance in the preparation of resource management plans and down to the recognition of individual property rights to individuals farmers claiming the tenure areas. To sustain these efforts, the project tests some alternative financing mechanisms for LGUs like the payments for environmental services (PES) as guarantee funds for environmental projects (though this is still on the testing stage). The PES mechanism is more dependent on institutional arrangements rather than the technical aspect of calculating how much to pay for environmental services.

Currently, EcoGov is working in 11 provinces and 130 municipalities and cities in four regions. There are two areas where CI-ICRAF project could work: 1) activities could compliment in those four regions that EcoGov is now working, and 2) to LGUs or peoples' organizations who could apply for the small grants for environmental projects e.g. biodiversity conservation projects.

\section{Filiberto Pollisco, Jr., ASEAN Centre for Biodiversity (ACB)}

ACB is currently in the process of institutionalization. There are four main programs; these are 1) Information and education campaign (IEC); 2) Knowledge Management; 3) Policy and program development; and 4) Resource Mobilization. For 2008 activities, the centre conducted a series of workshops on Community Concerned Areas (conducted in Malaysia). In February, the Protected Areas Management Course was held to capacitate PA managers. A Regional Ecotourism Development Workshop (participated by seven ASEAN countries) was conducted in March and it was highlighted that ecotourism will not flourish unless incorporated with some other activities e.g. this area demanding species which requires large landscape. Some countries have experienced that ecotourism will not flourish unless it will be linked with other environmental activities e.g. agricultural tourism. In April, an Urban Biodiversity Workshop was held in Singapore. This workshop will identify biodiversity indicators as well as will clarify some issues on assets and benefit sharing.

ACB is also busy in the harmonization of data for forest management and the Centre can share resource by jointly co-organizing training and workshops which will cater at least three ASEAN countries. 


\section{Identified Research Topics}

With the research and conservation implementation needs and priorities and how these could be fit into the regional development agendas, the following are the research needs. These research needs will be developed into full research proposals.

I. Area-demanding threatened species

\begin{tabular}{|c|c|c|}
\hline Small-scale Projects & $<100 K$ Projects & Pilot Project $\sim 100 \mathrm{~K}$ \\
\hline $\begin{array}{l}\text { 1. } \begin{array}{l}\text { Review of habitat } \\
\text { requirements of }\end{array} \\
\text { Philippine area- } \\
\text { demanding threatened } \\
\text { species; } \\
\text { 2. Philippine Eagle } \\
\text { telemetry scaled back } \\
\text { 3. Stable isotope work } \\
\text { (eagle, tamaraw, } \\
\text { pigeons, cockatoo) } \\
\text { 4. } \begin{array}{l}\text { Economics of area- } \\
\text { demanding threatened } \\
\text { frugivores in } \\
\text { agroforests* }\end{array} \\
\text { 5. Philippine Eagle feather } \\
\text { DNA (extent of } \\
\text { mortality and turn-over) }\end{array}$ & $\begin{array}{l}\text { 1. Philippine Eagle } \\
\text { telemetry: a) Luzon; b) } \\
\text { Mindanao wild; \& c) } \\
\text { Mindanao releases } \\
\text { 2. Habitat use by area- } \\
\text { demanding threatened } \\
\text { Philippine species (using } \\
\text { telemetry and } \\
\text { conventional fieldwork) } \\
\text { 3. Habitat suitability } \\
\text { analysis for Philippine } \\
\text { Eagle }\end{array}$ & $\begin{array}{l}\text { Corridors for movement and } \\
\text { corridors for prey, and } \\
\text { possibly combining them, } \\
\text { between known eagle habitat } \\
\text { and habitat not currently } \\
\text { known to hold eagles, } \\
\text { combined with education and } \\
\text { compensation for eagle-eaten } \\
\text { chickens* }\end{array}$ \\
\hline
\end{tabular}

* - could be a student work

* - This would take place exactly in Mt. Apo to Bukidnon (building on existing PEF project); Bukidnon to Eastern Mindanao; Zamboanga (Pasonanca north up the peninsula); and possibly also in Luzon (Aurora Mingan to IridAngelo). 
II. Landscape ecosystem processes

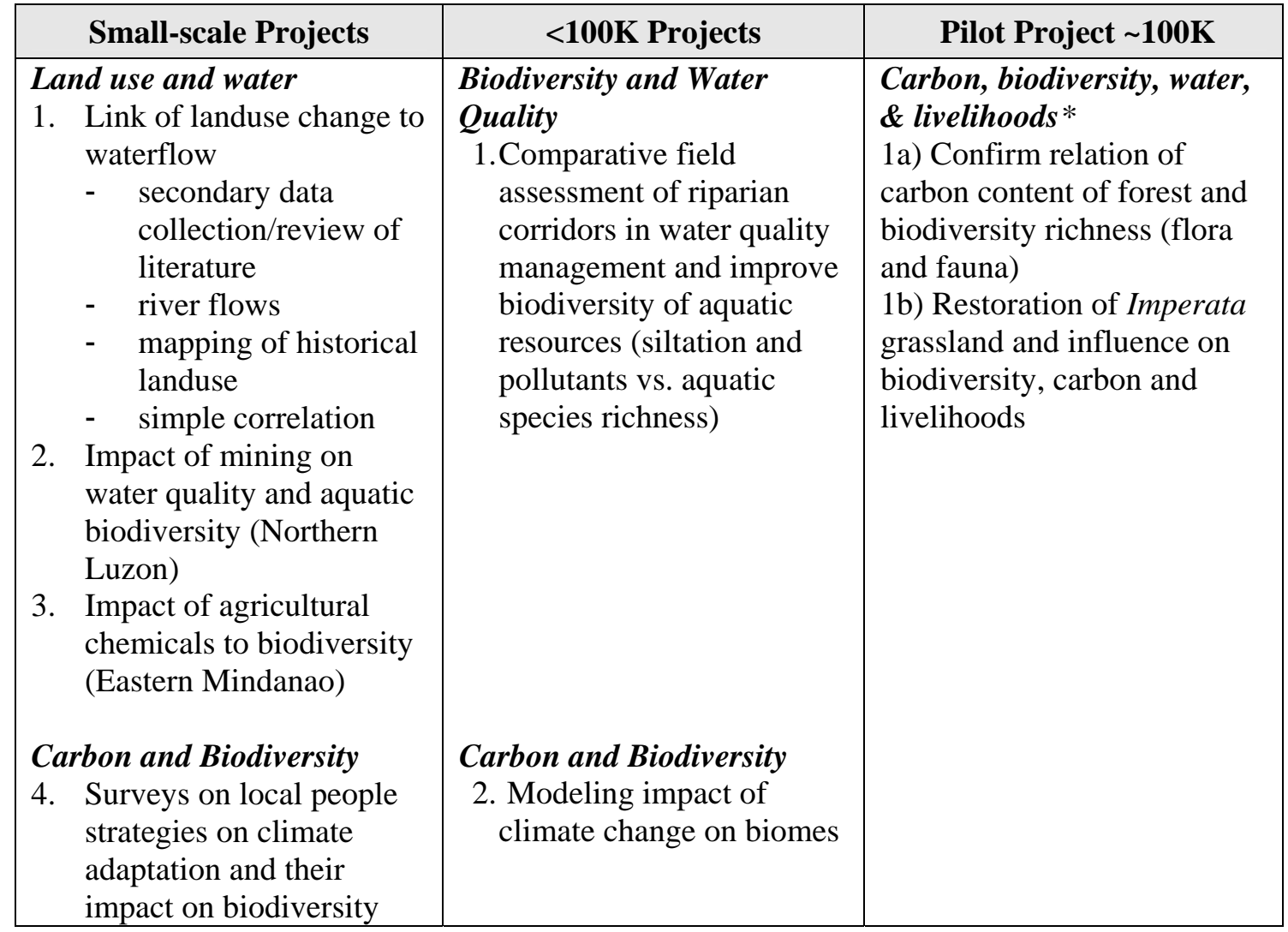

* Note: A 3-dimentional research approach and will be using different land use scenarios such as: a. biofuel; b. agroforestry; c. natural forest; d. tree-plantations; and e. agricultural plantations.

III. Context and Policies

\begin{tabular}{|c|c|}
\hline Recommended Research Needs & Research Component \\
\hline $\begin{array}{l}\text { 1. Policy study and research on } \\
\text { Jatropha (as input to the IRR for } \\
\text { appropriate implementation of the } \\
\text { Biofuel Act) (10K project) }\end{array}$ & $\begin{array}{ll}\text { - } & \text { Review existing literature (compendium } \\
\text { from PCARRD/DOST and other } \\
\text { experts) } \\
\text { - } \quad \text { Consultation with stakeholders at } \\
\text { different levels (local communities, } \\
\text { LGUs, Investment agencies/board of } \\
\text { Investments (BOI), private sectors and } \\
\text { public agencies (e.g. DOE, DENR, etc) }\end{array}$ \\
\hline $\begin{array}{ll}\text { 2. } & \text { Transboundary study } \\
\text { - } & \text { Developing appropriate institutional } \\
& \text { arrangement for Agusan Marsh } \\
& \text { Management; Cagayan River Basin } \\
& \text { and Arakan Valley }\end{array}$ & 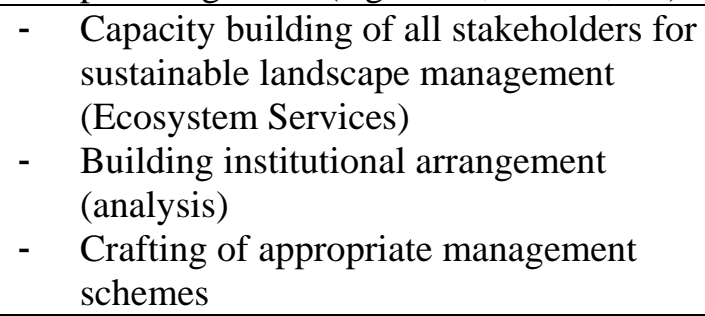 \\
\hline $\begin{array}{l}\text { 3. Priority implementable policy } \\
\text { projects }\end{array}$ & $\begin{array}{ll}\text { - } & \text { Information drive (IEC) on Biofuel Act } \\
\text { - } & \text { Social, economic, environmental } \\
\text { impacts of large-scale biofuel } \\
\text { production } \\
\text { - } & \text { Localizing climate change (indigenous } \\
\text { people reader friendly) for adaptation }\end{array}$ \\
\hline
\end{tabular}


For the context and policies, Biofuel became the main highlight of discussions due to the passage of the national law without consultations with different stakeholders at the ground level. The local government staff confirmed this that the copies of the law have not yet reached at their level. 


\section{Workshop Discussion}

During the general discussion, fundamental issues were raised. First, the recently enacted Biofuels Act posed hesitations and doubts due to the very limited information available (e.g. species and planting information and its environmental impacts). The Implementing Rules and Regulations (IRR) are still lacking. Second, the question of what management units for landscape scale conservation is appropriate. The issue is when the management requirement is beyond or cut across the political boundaries. Management and development plans at different levels must be addressed as well as its governance structures. Third, related to the first, is the issue of potential incentive instruments. Based on the shared experience from Arakan, investors are leasing the land (particularly for biofuel production) with an offer of 4,000 pesos/ha/yr (or approx. 100\$US) for a 25-year contract. PES schemes could be explored which provides livelihoods at the same time compatible to the conservation of ADTS. 


\section{Workshop Closing/Conclusion}

Thomas Brooks (CI) concluded the two-day meeting-workshop by providing the directions emerging from the activities. Moving towards prioritizing areas for multiple benefits of agroforestry expansion requires the following:

1. meeting the needs of area-demanding threatened species (esp. Philippine Eagle) that require landscape scale conservation;

2. addressing the maintenance of hydrological processes;

3. getting in front of emerging economic and policy trends especially carbon markets e.g. Clean Development Mechanisms (CDM) and biofuels; and

4. capacity building for landscape management and institutional arrangements at the appropriate scale.

Furthermore, specific opportunities to consider are:

- $\quad$ opportunities to overcome lack of data on the requirements of area-demanding threatened species (by definition they are hard to study, because they move!) presented by new satellite telemetry techniques; and

- $\quad$ opportunities presented for agroforestry by 'idle land' such as Imperata grassland to provide biodiversity, carbon, and livelihoods benefits, if ecological, economic, and institutional hurdles can be overcome. 


\section{Appendix I}

Programme of Activities

"Setting landscape conservation targets and promoting them through compatible land use in the Philippines"

\section{Conservation International (CI) and World Agroforestry Centre (ICRAF) Philippines Project Meeting}

Training Center for Tropical Resources and Ecosystems Sustainability (TREES), University of the Philippines Los Baños (UPLB), Laguna

11-12 April 2008

Day 1

\begin{tabular}{|c|c|}
\hline 08:30-09:00 & Registration \\
\hline 09:00-09:10 & $\begin{array}{l}\text { Welcome Remarks: } \\
\text { Corazon A. Calimag, TREES, UPLB }\end{array}$ \\
\hline 09:10-09:30 & $\begin{array}{l}\text { Introductory Remarks: } \\
\text { Rodel D. Lasco, ICRAF - Philippines } \\
\text { Romy Trono, CI-Philippines }\end{array}$ \\
\hline $09: 30-09: 45$ & Introduction of Participants \\
\hline 09:45-10:05 & $\begin{array}{l}\text { Synergies between sustainable rural development and biodiversity } \\
\text { conservation - the rationale for the CI-ICRAF Global Collaboration } \\
\text { Jean-Marc Boffa, ICRAF - Kenya }\end{array}$ \\
\hline $10: 05-10: 25$ & $\begin{array}{l}\text { Contributions of agroforestry to landscape scale conservation - a global } \\
\text { perspective } \\
\text { Goetz Schroth, CI- Conservation Strategies Division }\end{array}$ \\
\hline $10: 25-10: 45$ & $\begin{array}{l}\text { Agroforestry in the landscape in Southeast Asia: landuse system, local } \\
\text { livelihood strategies and trends } \\
\text { Rodel D. Lasco - ICRAF - Philippines }\end{array}$ \\
\hline $10: 45-11: 00$ & Coffee break \\
\hline $11: 00-11: 20$ & $\begin{array}{l}\text { Background of CI-ICRAF Project in the Philippines } \\
\text { Thomas Brooks, CI- CABS }\end{array}$ \\
\hline $11: 20-11: 40$ & $\begin{array}{l}\text { Ecology and conservation status of the Philippine Eagle, a species in need } \\
\text { of landscape scale conservation } \\
\text { Todd Katzner, National Aviary, USA; Jayson Ibanez, Philippine Eagle } \\
\text { Foundation (PEF); Nigel Collar, Birdlife International, UK }\end{array}$ \\
\hline $11: 40-12: 00$ & $\begin{array}{l}\text { A new approach to define landscape conservation targets based on species } \\
\text { needs - results from the CI-ICRAF cooperation } \\
\text { Karl L. Villegas, Leiden University- Isabela State University } \\
\text { Grace B. Villamor, ICRAF-Philippines }\end{array}$ \\
\hline $12: 00-01: 15$ & LUNCH \\
\hline $01: 15-01: 45$ & $\begin{array}{l}\text { Landscape level conservation and the Philippine Eagle in the Sierra Madre } \\
\text { Range } \\
\text { (1) Mariano Duya, CI-Philippines } \\
\text { (2) Merlijn van Weerd, Cagayan Valley Programme on Environment } \\
\text { and Development (CVPED), the Netherlands }\end{array}$ \\
\hline $01: 45-02: 15$ & $\begin{array}{l}\text { Landscape level conservation and the Philippine Eagle in Eastern } \\
\text { Mindanao Range } \\
\text { (1) Lito Cereno, Philippine Eagle Foundation (PEF) } \\
\text { (2) Delia Catacutan, ICRAF - Philippines }\end{array}$ \\
\hline
\end{tabular}




\begin{tabular}{|c|l|}
\hline $02: 15-05: 00$ & $\begin{array}{l}\text { Break-out groups on research and conservation implementation needs and } \\
\text { priorities to meet the targets emerging from the project: } \\
\text { (1) Landscape level conservation of the Philippine Eagle, an area- } \\
\text { demanding threatened species (Science research group) } \\
\text { (2) Conserving landscape ecosystem processes on which biodiversity } \\
\text { depends (Ecosystem processes group) } \\
\text { (3) Context and Policies affecting the landscape conservation } \\
\text { (Context and policy group) } \\
\text { Facilitators: } \\
\text { Oliver Coroza, Grace Ambal, CI-Philippines, and } \\
\text { Antonio Manila, Protected Area and Wildlife Bureau (PAWB) }\end{array}$ \\
\hline
\end{tabular}

Day 2

\begin{tabular}{|c|c|}
\hline Time & Agenda \\
\hline $08: 15-08: 30$ & Registration \\
\hline $08: 30-08: 45$ & $\begin{array}{l}\text { Integrating livelihoods and multiple biodiversity values in landscape } \\
\text { mosaics based on the CIFOR-ICRAF Landscape Mosaic Project } \\
\text { Jean-Marc Boffa, ICRAF - Kenya }\end{array}$ \\
\hline $08: 45-09: 30$ & Presentations of break-out groups and discussion \\
\hline $09: 30-09: 45$ & Coffee break \\
\hline 09:45-12:00 & $\begin{array}{l}\text { How does landscape scale conservation fit into the regional development } \\
\text { agendas? Panel discussion with representatives from the Public and } \\
\text { Private Sectors and Bilateral Agencies: } \\
\text { - } \quad \text { DENR - PAWB (Department of Environment and Natural Resources- } \\
\text { - } \quad \text { Protected Areas and Wildlife Bureau) } \\
\text { - } \quad \text { University of the Philippines Mindanao } \\
\text { - } \quad \text { EcoGov-USAID } \\
\text { - } \quad \text { Mt. Kitangland Agri-Venture Inc. - Unifrutti } \\
\text { - } \quad \text { ASEAN Centre for Biodiversity (ACB) } \\
\text { Facilitator: } \\
\text { Artem Antolin, CI-Philippines }\end{array}$ \\
\hline $12: 00-01: 00$ & LUNCH \\
\hline $01: 00-03: 30$ & $\begin{array}{l}\text { The Practicalities: Partnerships, joint proposal development, } \\
\text { communications, etc. } \\
\text { Break-out groups } \\
\text { Facilitator: Ruth Grace Ambal, CI-Philippines }\end{array}$ \\
\hline $03: 30-03: 45$ & Coffee break \\
\hline 03:45- 05:00 & Presentations of break-out groups and discussion \\
\hline
\end{tabular}




\section{Appendix II}

List of Participants

\begin{tabular}{|c|c|}
\hline $\begin{array}{l}\text { Ambal, Ruth Grace R. } \\
\text { Conservation International Philippines } \\
\text { 6 Maalalahanin Street Teacher’s Village } \\
\text { Quezon City 1101 Philippines } \\
\text { Tel: +632 924-8235/ 433-5129/ 4338429 } \\
\text { Fax: +632 435-6446 } \\
\text { Email: r.ambal@conservation.org }\end{array}$ & $\begin{array}{l}\text { Boulanger, Desiree } \\
\text { Phone: +63 9292950256 } \\
\text { Email: boulangersd@yahoo.fr }\end{array}$ \\
\hline $\begin{array}{l}\text { Antolin, Artem } \\
\text { Conservation International Philippines } \\
\text { 6 Maalalahanin Street Teacher’s Village } \\
\text { Quezon City 1101 Philippines } \\
\text { Tel: +63 } 29248235 \\
\text { Email: a.antolin@conservation.org }\end{array}$ & $\begin{array}{l}\text { Brookes, Thomas M. } \\
\text { Conservation Synthesis Department } \\
\text { Center for Applied Biodiversity Science } \\
\text { Conservation International } \\
\text { 2011 Crystal Drive, Suite } 500 \text {, Arlington VA } \\
22202 \text {, USA } \\
\text { Tel: +1-703-341-2727 } \\
\text { Fax: +1-703-979-1208 } \\
\text { Email: t.brookes@conservation.org }\end{array}$ \\
\hline $\begin{array}{l}\text { Antolin, Restituta } \\
\text { Department of Environment and Natural } \\
\text { Resources } \\
\text { Carig, Tuguegarao City } \\
\text { Tel: (078) } 8467544 \\
\text { Fax: (078) } 8448037\end{array}$ & $\begin{array}{l}\text { Catacutan, Delia } \\
\text { Research Manager } \\
\text { Avocado Road, Casisang, } \\
\text { 8700 Malaybalay City } \\
\text { Tel: } 088221 \text { 3187; } \\
\text { Telefax: } 099 \text { 2213859 } \\
\text { Email: delia_icraf@yahoo.com }\end{array}$ \\
\hline $\begin{array}{l}\text { Baylomo, Renato } \\
\text { Mt. Kitanglad Agri-Venture Incorporated } \\
\text { Rm } 220 \text { Narra Bldg } \\
\text { 2276 Pasong Tamo Ext } \\
\text { Makati City }\end{array}$ & $\begin{array}{l}\text { Cereno, Angelito } \\
\text { Philippine Eagle Foundation } \\
\text { VAL Learning Village, } \\
\text { Ruby St., Marfori Heights, } \\
\text { Davao City } 8000 \text { Philippines } \\
\text { Telephone: (+63 82) 224-3021 } \\
\text { Telefax: (+63 82) 224-3022 } \\
\text { Email: phileagl@pldtdsl.net }\end{array}$ \\
\hline $\begin{array}{l}\text { Boffa, Jean-Marc Jacques } \\
\text { Biodiversity and Domestication Specialist } \\
\text { Research and Development } \\
\text { ILB Rm G115 } \\
\text { ICRAF Nairobi } \\
\text { Kenya } \\
\text { Tel: + 254207224145 } \\
\text { Email: j.boffa@cgiar.org }\end{array}$ & $\begin{array}{l}\text { Coroza, Oliver } \\
\text { Conservation International Philippines } \\
6 \text { Maalalahanin Street Teacher’s Village } \\
\text { Quezon City } 1101 \text { Philippines } \\
\text { Tel: +63 } 29248235 \\
\text { Email: o.coroza@conservation.org }\end{array}$ \\
\hline $\begin{array}{l}\text { Boquiren, Rowena } \\
\text { Conservation International Philippines } \\
6 \text { Maalalahanin Street Teacher’s Village } \\
\text { Quezon City } 1101 \text { Philippines } \\
\text { Tel: +632 } 9248235\end{array}$ & $\begin{array}{l}\text { Delfino, Rafaela Jane } \\
\text { Researcher } \\
\text { ICRAF Philippines } \\
\text { Khush Hall, IRRI, Los Baños } \\
\text { Laguna }\end{array}$ \\
\hline
\end{tabular}




\begin{tabular}{|c|c|}
\hline Email: r.boquiren@conservation.org & $\begin{array}{l}\text { Tel: +6349 } 5362607 \text { loc. } 2675 \\
\text { Email: r.delfino@cgiar.org }\end{array}$ \\
\hline $\begin{array}{l}\text { Dolom, Bien } \\
\text { EcoGov } \\
\text { U.S. Agency for International Development } \\
\text { 8/F PNB Center } \\
\text { Pres. Diosdado Macapagal Boulevard } \\
\text { Pasay City, Philippines } 1308 \\
\text { Cellphone: +639152751315 } \\
\text { Email: bldolom@yahoo.com }\end{array}$ & $\begin{array}{l}\text { Masipiquena, Andres } \\
\text { Program Coordinator } \\
\text { Cagayan Valley Program on Environment } \\
\text { and Development (CVPED) } \\
\text { ISU-Cabagan, } \\
\text { 3328 Isabela, The Philippines } \\
\text { Email: cvpedgarita@yahoo.com }\end{array}$ \\
\hline $\begin{array}{l}\text { Duya, Mariano Roy } \\
\text { Conservation International Philippines } \\
6 \text { Maalalahanin Street Teacher’s Village } \\
\text { Quezon City } 1101 \text { Philippines } \\
\text { Tel: +63 } 29248235 \\
\text { Email: m.duya@conservation.org }\end{array}$ & $\begin{array}{l}\text { Opiso, Guiller } \\
\text { Philippine Eagle Foundation } \\
\text { VAL Learning Village, } \\
\text { Ruby St., Marfori Heights, } \\
\text { Davao City } 8000 \text { Philippines } \\
\text { Telephone: (+63 82) 224-3021 } \\
\text { Telefax: (+63 82) 224-3022 } \\
\text { Email: phileagl@pldtdsl.net }\end{array}$ \\
\hline $\begin{array}{l}\text { James, Roger } \\
\text { Conservation International } \\
\text { Malesiana CBC, } \\
\text { P.O. Box 780, Atherton, Queensland } \\
\text { Australia 4883 } \\
\text { Email: r.james@conservation.org }\end{array}$ & $\begin{array}{l}\text { Oponda, Nilo } \\
\text { College of Science and Mathematics } \\
\text { University of the Philippines Mindanao } \\
\text { Bago Oshiro, Tugbok } \\
\text { Email: nilooponda@yahoo.com }\end{array}$ \\
\hline $\begin{array}{l}\text { Katzner, Todd } \\
\text { Director of Conservation and Field Research } \\
\text { National Aviary } \\
700 \text { Arch St. } \\
\text { Allegheny Commons West } \\
\text { Pittsburgh, PA 15212-5248 USA } \\
\text { E-mail: todd.katzner@aviary.org } \\
\text { Tel: 412.323.7235 ext. } 210 \\
\text { Fax: 412.321.4364 }\end{array}$ & $\begin{array}{l}\text { Pabilona, Victor Adrian L. } \\
\text { Mt. Kitanglad Agri-Venture Incorporated } \\
\text { Rm } 220 \text { Narra Bldg } \\
2276 \text { Pasong Tamo Ext } \\
\text { Makati City } \\
\text { Email: vicjmc04@yahoo.com }\end{array}$ \\
\hline $\begin{array}{l}\text { Lasco, Rodel D. } \\
\text { Country Coordinator } \\
\text { ICRAF Philippines } \\
\text { Khush Hall, IRRI, Los Baños } \\
\text { Laguna } \\
\text { Tel: +6349536 } 2607 \text { loc. } 2675 \\
\text { Email: r.lasco@cgiar.org }\end{array}$ & $\begin{array}{l}\text { Peteros, Ricardo } \\
\text { Coordinator, Eastern Mindanao Biodiversity } \\
\text { Corridor } \\
\text { Conservation International-Philippines } \\
\text { EM office, Liboon Subd. Purok3 -A } \\
\text { Ampaao, Butuan City } \\
\text { Tele/Fax: (085) } 3425728 \\
\text { Cel: 09189077369 } \\
\text { Email: rpeteros@conservation.org }\end{array}$ \\
\hline $\begin{array}{l}\text { Manila, Antonio } \\
\text { Division Chief, Wildlife Resources Division } \\
\text { Protected Areas and Wildlife Bureau } \\
\text { (PAWB), Dept of Environment and Natural } \\
\text { Resources (DENR), North Aven., Dilliman } \\
\text { Quezon City. Philippines } \\
\text { E-mail: acmanila@hotmail.com }\end{array}$ & $\begin{array}{l}\text { Pollisco, Filiberto Jr. } \\
\text { ASEAN Centre for Biodiversity (ACB) } \\
\text { Policy and Program Development Specialist } \\
\text { ASEAN Centre for Biodiversity (ACB) } \\
\text { 3rd Floor, ERDB Bldg. Forestry Campus } \\
\text { University of the Philippines (UPLB) } \\
\text { College, Laguna 4031,Philippines }\end{array}$ \\
\hline
\end{tabular}




\begin{tabular}{|c|c|}
\hline & $\begin{array}{l}\text { Telfax: (+63-49) 536-2865/ 536-1044 } \\
\text { E-mail: duknoy@yahoo.com; } \\
\text { fapollisco@aseanbiodiversity.org }\end{array}$ \\
\hline $\begin{array}{l}\text { Reovoca, Leonardo } \\
\text { Municipal Councilor } \\
\text { Sanggunian Bayan (SB) Chairperson of the } \\
\text { Environment Committee } \\
\text { Arakan, Cotabato }\end{array}$ & $\begin{array}{l}\text { Villamor, Grace B. } \\
\text { Assistant Scientist } \\
\text { ICRAF Philippines } \\
\text { Khush Hall, IRRI, Los Baños } \\
\text { Laguna } \\
\text { Tel: +63 } 495362607 \text { loc. } 2675 \\
\text { Mob: +639192330384 } \\
\text { Email: g.villamor@cgiar.org } \\
\quad \text { agila_ph@yahoo.com }\end{array}$ \\
\hline $\begin{array}{l}\text { Schroth, Götz } \\
\text { Senior Advisor, Land Use Strategies } \\
\text { Conservation International } \\
\text { 2011 Crystal Drive, Suite } 500 \\
\text { Arlington, VA 22202, USA } \\
\text { Phone: (703) 341-2508 } \\
\text { E-mail: g.schroth@conservation.org }\end{array}$ & $\begin{array}{l}\text { Villegas, Karl Abelard L. } \\
\text { Institute of Environmental Sciences (CML), } \\
\text { Leiden University } \\
\text { PO Box 9518, 2300 RA Leiden, } \\
\text { The Netherlands } \\
\text { Tel: +31 (0)71 } 5277482 \\
\text { Fax: +31(0)71 } 5277496 \\
\text { Mob: +31(0)6 24747896 } \\
\text { Email: k.villegas@yahoo.com.ph } \\
\text { Web: www.leidenuniv.nl/cml }\end{array}$ \\
\hline $\begin{array}{l}\text { Trono, Romeo } \\
\text { Country Executive Director } \\
\text { Conservation International Philippines } \\
6 \text { Maalalahanin Street Teacher’s Village } \\
\text { Quezon City 1101 Philippines } \\
\text { Tel: +63 } 29248235 \\
\text { Email: r.trono@conservation.org }\end{array}$ & \\
\hline $\begin{array}{l}\text { van Weerd, Merlijn } \\
\text { Program Coordinator CVPED } \\
\text { CROC Team Leader } \\
\text { Email: vanweerd@cml.leidenuniv.nl } \\
\quad \text { merlijnvanweerd@yahoo.com } \\
\text { Institute of Environmental Sciences (CML), } \\
\text { Leiden University } \\
\text { PO Box 9518, } 2300 \text { RA Leiden, The } \\
\text { Netherlands } \\
\text { Tel: +31 (0)71 } 5277482 \\
\text { Fax: +31 (0)71 5277496 } \\
\text { Mob: +31 (0)6 } 24747896 \\
\text { Web: www.leidenuniv.nl/cml }\end{array}$ & \\
\hline
\end{tabular}




\section{References}

Harvey et al,. 2008. Integrating Agricultural Landscapes with Biodiversity Conservation in the Mesoamerican Hotspot. Conservation Biology. Vol. 22 (1) pp.8-15. 


\section{Working Paper Series}

2003-2005

1. Eco-Certification as an Incentive to Conserve Biodiversity in Rubber Smallholder Agroforestry Systems: A Preliminary Study

2. RUPES: A Review of Initiatives from Developed Countries

3. Development Assistance to Upland Communities in The Philippines

4. Forest Area Rationalization in Indonesia: A Study on The Forest Resource Condition and Policy Reform

5. Environmental Service "Payments": Experiences, Constraints and Potential in The Philippines

6. Assessing the Livelihood Benefits to Local Communities from the Profafor Carbon Sequestration Project, Ecuador

7. An Introduction to the Conceptual Basis of RUPES

8. Review of Developments of Environmental Services Markets in Sri Lanka

9. Rewards for Environmental Services in the Philippines Uplands: Constraints and Opportunities for Institutional Reform

10. Case Study of the Maasin Watershed: Analyzing the Role of Institutions in a Watershed-Use Conflict

11. Rapid Agrobiodiversity Assessment (RABA): A tool to capture the understanding and knowledge of stakeholders on the benefits of agrobiodiversity

12. Rewarding Upland Farmers for Environmental Services: Experience, Constraints, and Potential in Vietnam

13. Institutional Constraints and Opportunities in Developing Environmental Service Markets: Lessons from Institutional Studies on RUPES in Indonesia

14. Review of Developments of Environmental Services Markets in Indonesia

15. RUPES Typology of Environmental Service Worthy of Reward

1. Report on the Self-Evaluation Study of RUPES

1. Participatory poverty and livelihood assessment report, Kalahan, Nueva Vizcaya, the Philippines

2. Carbon Storage of the Grassland Areas of Ikalahan Ancestral Domain, Nueva Vizcaya, Philippines 


\section{Who we are}

The World Agroforestry Centre is the international leader in the science and practice of integrating 'working trees' on small farms and in rural landscapes. We have invigorated the ancient practice of growing trees on farms, using innovative science for development to transform lives and landscapes.

\section{Our vision}

Our Vision is an 'Agroforestry Transformation' in the developing world resulting in a massive increase in the use of working trees on working landscapes by smallholder rural households that helps ensure security in food, nutrition, income, health, shelter and energy and a regenerated environment.

\section{Our mission}

Our mission is to advance the science and practice of agroforestry to help realize an 'Agroforestry Transformation' throughout the developing world.

\section{F UTURE HA RY/ES T CGIAR}

A Future Harvest Centre supported by the CGIAR

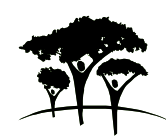

United Nations Avenue, Gigiri - PO Box 30677 - 00100 Nairobi, Kenya Tel: +254 207224000 or via USA +1 6508336645

Fax: +254207224001 or via USA +16508336646

Southeast Asia Regional Programme - Sindang Barang, Bogor 16680 PO Box161 Bogor 16001, Indonesia

Tel: +62 251625415 - Fax: +62 251625416

www.worldagroforestry.org 